\title{
Optimalisasi Fungsi Perencanaan pada Program Pendidikan dan Pelatihan Tenaga Teknis Keagamaan di Balai Diklat Keagamaan Bandung
}

\author{
Yini Adicahya ${ }^{1 *}$ \\ ${ }_{1}^{1}$ Jurusan Manajemen Dakwah, Fakultas Dakwah dan Komunikasi, Universitas Islam Negeri \\ Sunan Gunung Djati Bandung ${ }^{1}$; \\ Email:yini.adicahya@gmail.com ${ }^{1}$
}

\begin{abstract}
ABSTRAK
Tujuan dari penelitian ini adalah untuk mengetahui bagaimana optimalisasi fungsi perencanaan pada program pendidikan dan pelatihan tenaga teknis keagamaan di Balai Diklat Keagamaan Bandung. Adapun metode yang digunakan dalam penelitian ini adalah metode deskriptif. Dari hasil penelitian ini, diperoleh informasi bahwa proses perencanaan yang dilakukan Balai Diklat Keagamaan Bandung meliputi: melakukan AKD, melakukan rapat koordinasi dengan satuan organisasi di wilayah kerja Balai Diklat, menentukan panitia, mengadakan rapat persiapan, menentukan waktu dan tempat, menetapkan peserta, narasumber dan moderator, menyusun jadwal dan panduan, menyiapkan sarana prasarana, dan terakhir membuat laporan persiapan. Adapun yang menjadi factor pendukung perencanaan diklat tenaga teknis keagamaan adalah tenaga kediklatan, program diklat, kurikulum, sarana prasarana, metode, media, materi, dan lain-lain. Sedangkan yang menjadi factor penghambat adalah terbatasnya anggaran dari pemerintah dan peserta yang seringkali tidak sesuai dengan anggaran. Selanjutnya, strategi yang diterapkan BDK Bandung dalam mengoptimalkan proses perencanaan pada program diklat tenaga teknis keagamaan adalah dengan senantiasa mengikuti standar kediklatan yang telah ditentukan, mengadakan sistem penjaminan mutu diklat teknis, berlandaskan pada pedoman penyelenggaraan diklat, menyelenggarakan Diklat Kerja Sama, dan senantiasa melakukan koordinasi dengan satuan organisasi di wilayah kerja Balai Diklat.
\end{abstract}

Kata kunci: optimalisasi; perencanaan; pendidikan dan pelatihan 


\section{ABSTRACT}

The purpose of this study was to determine how to optimize the planning function in the education and training program for religious technical personnel at the Bandung Religious Education and Training Center. The method used in this research is descriptive method. From the results of this study, information was obtained that the planning process carried out by the Bandung Religious Education and Training Center included: conducting AKD, conducting coordination meetings with organizational units in the work area of the Education and Training Center, determining committees, holding preparatory meetings, determining time and place, assigning participants, resource persons and moderator, compiling schedules and guidelines, preparing infrastructure, and finally making a preparatory report. As for the supporting factors for the planning of training for religious technical personnel are education and training programs, curriculum, infrastructure, methods, media, materials, and others. Meanwhile, the inbibiting factor is the limited budget from the government and participants, which often does not match the budget. Furthermore, the strategy applied by BDK Bandung in optimizing the planning process in the training program for religious technical personnel is to always follow predetermined educational standards, establish a quality assurance system for technical education and organizational units in the work area of the Training Center.

Keywords: optimization; planning; education and training

\section{PENDAHULUAN}

Di era globalisasi dan modernisasi seperti sekarang ini, perkembangan ilmu pengetahuan dan teknologi (IPTEK) tidak dapat terbendung lagi. Pesatnya perkembangan IPTEK tersebut telah menyentuh dan mengubah berbagai sektor kehidupan seperti sosial, ekonomi, politik, budaya, dan bahkan lembaga keagamaan. Berbagai perubahan tersebut mengakibatkan persaingan hidup yang semakin ketat, dan hal ini dirasakan baik oleh individu maupun organisasi. Sehingga setiap individu maupun organisasi berusaha untuk mempertahankan eksistensinya dengan senantiasa meningkatkan produktivitasnya.

Dalam sebuah lembaga atau organisasi terdapat unsur-unsur manajemen yang penting dalam menentukan keberhasilan lembaga tersebut, yaitu man, money, methods, materials, machines, and market atau disingkat 6 M (Hasibuan, 2006: 20).

Setiap unsur manajemen tersebut memiliki peranan penting dalam pencapaian tujuan lembaga atau organisasi. Namun yang terpenting dari keenam unsur tersebut adalah unsur manusia, karena tanpa manusia, maka unsur-unsur yang lain tidak dapat berjalan, karena manusialah yang menjadi pusat pengendali kelima unsur lainnya. Oleh karena itu, sumber daya manusia yang profesional sangat diperlukan oleh setiap lembaga dalam mencapai tujuannya.

Sumber Daya Manusia (SDM) yang profesional dapat dicapai melalui upaya pengembangan SDM yang terarah dan terencana. Pengembangan SDM 
diperlukan untuk meningkatkan potensi, pengetahuan dan wawasan, keterampilan kerja, kemampuan manajerial, sikap dan kepribadian, serta faktor-faktor lain yang terdapat dalam diri manusia(Alfarisi, 2009: 1).

Dalam penyelenggaraan negara dan pembangunan, saat ini Pemerintah Negara Indonesia dihadapkan pada tuntutan nasional dan tantangan global untuk mewujudkan pemerintahan yang baik. Oleh karena itu, diperlukan sumber daya manusia aparatur yang memiliki kompetensi tinggi.

Untuk mewujudkan hal tersebut diperlukan peningkatan mutu profesionalisme dan pengembangan wawasan Pegawai Negeri Sipil. Upaya yang telah ditempuh oleh pemerintah dalam peningkatan mutu profesionalisme dan pengembangan wawasan Pegawai Negeri Sipil adalah melalui program pendidikan dan pelatihan (Diklat) (Tulung, 2014: 1).

Oleh karena itu Kementerian Agamapun melakukan berbagai upaya dalam rangka membentuk PNS Kementerian Agama untuk dapat menjadi contoh dan teladan bagi masyarakat, memiliki akhlak mulia, profesional, disiplin dan bertanggungjawab dalam menyelenggarakan tugas pemerintahan dan pembangunan (Tulung, 2014: 1-2).

Upaya yang dilakukan Kementerian Agama dalam membentuk PNS sebagai aparatur negara yang profesional adalah melalui program pendidikan dan pelatihan (Diklat). Hal tersebut sesuai dengan Peraturan Menteri Agama Nomor 75 Tahun 2015 tentang Penyelenggaraan Pendidikan dan Pelatihan Pegawai pada Kementerian Agama, yaitu "Untuk mewujudkan Sumber Daya Manusia Kementerian Agama yang berkualitas, profesional, berintegritas, dan bertanggungjawab, perlu diselenggarakan pendidikan dan pelatihan pegawai”.

Pentingnya sebuah pelatihan juga diisyaratkan dalam firman Allah QS. ArRo'd ayat 11, sebagai berikut:

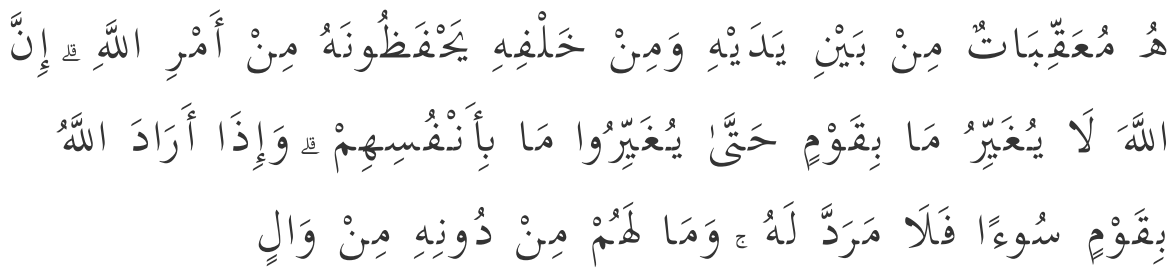

"Bagi manusia ada malaikat-malaikat yang selalu mengikutinya bergiliran, di muka dan di belakangnya, mereka menjaganya atas perintah Allah. Sesungguhnya Allah tidak merubah keadaan sesuatu kaum sehingga mereka merubah keadaan yang ada pada diri mereka sendiri. Dan apabila Allah menghendaki keburukan terhadap sesuatu kaum, maka tak ada yang dapat menolaknya; dan sekali-kali tak ada pelindung bagi mereka selain Dia(QS.Ar.Ro'd: 11). 
Namun demikian, keberhasilan penyelenggaraan suatu program pelatihan antara lain terletak pada kemampuan pengelola latihan dalam mengelola setiap program kegiatan. Dengan kata lain, penerapan aspek-aspek manajemen dalam program ini mutlak diperlukan (Kusnawan, et.al, 2009: 22).

Aspek-aspek manajemen tersebut menurut Harold Koontz \& Cyril O'Donnel dalam Hasibuan (2011:38) terdiri dari planning, organizing, staffing, directing and controlling.

Perencanaan (planning) adalah fungsi dasar (fundamental) manajemen, karena organizing, staffing, directing dan controllingpun harus terlebih dahulu direncanakan (Hasibuan: 2011: 91). Tanpa adanya rencana, maka tidak ada dasar untuk melaksanakan kegiatan-kegiatan tertentu dalam rangka mencapai tujuan. Jadi perencanaan memiliki peran yang signifikan, karena ia merupakan dasar dan titik tolak dari kegiatan pelaksanaan selanjutnya (Munir, et.al, 2009: 94-95). Oleh karena itu, agar proses pelatihan dapat memperoleh hasil yang maksimal, maka perencanaan di sini merupakan sebuah keharusan.

Pelatihan memang merupakan pekerjaan yang tidak mudah, karena ia berkaitan dengan peningkatan kualitas sumber daya manusia yang lebih tangguh, kompetitif dan berdaya saing. Oleh karena itu, untuk dapat menyelenggarakan suatu program pelatihan secara efektif, setiap lembaga diklat harus mematangkan perencanaan terlebih dahulu. Karena tidak jarang gagalnya sebuah program bukan hanya disebabkan oleh pelaksanaan yang tidak maksimal melainkan karena perencanaan yang tidak matang.

Balai Diklat Keagamaan Bandung adalah salah satu unit pelaksana teknis pendidikan dan pelatihan yang berada di bawah dan bertanggungjawab kepada Badan Litbang dan Diklat Kementerian Agama RI. Dasar hukum yang melandasi keberadaan lembaga ini adalah Keputusan Menteri Agama (KMA) Nomor 345 Tahun 2004.

Berdasarkan hasil observasi awal, peneliti menemukan bahwa sejauh ini penerapan fungsi manajemen di Balai Diklat Keagamaan Bandung sudah baik, bahkan menurut Kepala Seksi Diklat Tenaga Teknis Keagamaan menuturkan bahwa "Penyelenggaraan program diklat di Balai Diklat Keagamaan Bandung bisa dikatakan efektif". Dalam hal ini, kegiatan perencanaan memberikan peranan yang sangat signifikan dalam pelaksanaan program dan pencapaian tujuan diklat. Sebelum menyelenggarakan suatu program biasanya Balai Diklat mengadakan Analisis Kebutuhan Diklat (AKD) terlebih dahulu ke setiap daerah, kemudian hasil dari AKD tersebut disesuaikan dengan anggaran yang ada berdasarkan prioritas. Selanjutnya Balai Diklat mengadakan Rakor (rapat koordinasi) dengan satuan organisasi di daerah seperti Kanwil Kemenag Provinsi, Kemenag Kota/Kabupaten, Pengadilan Tinggi Agama, UIN/IAIN, STAIN, STAKN, serta 
STAHN untuk menyepakati hasil dari AKD tersebut. Selanjutnya, dalam merealisasikan fungsi perencanaan, Balai Diklat Keagamaan Bandung mengikuti standar kediklatan yang telah ditentukan oleh pusat, seperti dalam merumuskan tujuan, sasaran, metode, media, kurikulum, serta unsur pelatihan lainnya (wawancara dengan Kasubag TU, Ade Suryaman, 08 Agustus 2016).

Oleh karena itu, penulis tertarik untuk melakukan penelitian dengan mengambil judul "Optimalisasi Fungsi Perencanaan pada Program Pendidikan dan Pelatihan Tenaga Teknis Keagamaan Di Balai Diklat Keagamaan Bandung”. Lokasi penelitian ini tepatnya berada di Jl. Soekarno-Hatta No. 716 Bandung.

Berdasarkan pada latar belakang masalah yang telah diuraikan di atas, maka masalah pokok yang akan dibahas dalam penelitian ini dirumuskan sebagai berikut :1) Bagaimana proses perencanaan yang dilakukan Balai Diklat Keagamaan Bandung dalam menyelenggarakan program diklat tenaga teknis keagamaan? 2) Apa faktor pendukung dan penghambat proses perencanaan pada program diklat tenaga teknis keagamaan di Balai Diklat Keagamaan Bandung? 3) Bagaimana strategi yang dilakukan Balai Diklat Keagamaan Bandung dalam mengoptimalkan fungsi perencanaan pada program diklat tenaga teknis keagamaan? Adapun metode yang digunakan dalam penelitian ini adalah metode deskriptif.

\section{LANDASAN TEORITIS}

Pengembangan sumber daya manusia (SDM) adalah penyiapan manusia atau karyawan untuk memikul tanggung jawab yang lebih tinggi dalam organisasi atau perusahaan. Pengembangan SDM berpijak pada fakta bahwa setiap tenaga kerja membutuhkan pengetahuan, keahlian, dan keterampilan yang lebih baik. Pengembangan juga membantu para karyawan untuk mempersiapkan diri dalam menghadapi perubahan pekerjaan atau jabatan yang akan diakibatkan oleh adanya teknologi baru atau pasar produk baru (Samsudin, 2010: 107).

Tujuan pokok program pengembangan SDM adalah meningkatkan kemampuan, keterampilan, sikap dan tanggung jawab karyawan sehingga lebih efektif dan efisien dalam mencapai sasaran program dan tujuan organisasi.

Pendidikan dan pelatihan merupakan salah satu upaya dalam mengembangkan SDM terutama untuk mengembangkan kemampuan intelektual dan kepribadian manusia. Oleh karena itu untuk memperoleh hasil yang maksimal dalam pengembangan pegawai diperlukan program pendidikan dan pelatihan yang sesuai dengan analisa jabatan agar pegawai mengetahui tujuan pendidikan dan pelatihan yang diikutinya.

Dalam Peraturan Menteri Agama Nomor 75 Tahun 2015 tentang Penyelenggaraan Pendidikan dan Pelatihan Pegawai pada Kementerian Agama, menyatakan bahwa "Yang dimaksud dengan pendidikan dan pelatihan yang 
selanjutnya disebut Diklat adalah penyelenggaraan pembelajaran dan pelatihan dalam rangka mengembangkan kompetensi pegawai sesuai persyaratan jabatan masing-masing pada Kementerian Agama”.

Menurut Gomes (1997: 197) yang dikutip dalam buku Manajemen Sumber Daya Manusia Strategik (Sulastri, 2010: 150) mengemukakan bahwa, "Pelatihan merupakan setiap usaha untuk memperbaiki prestasi kerja pada suatu pekerjaan tertentu yang sedang menjadi tanggungjawabnya. Idealnya, pelatihan harus dirancang untuk mewujudkan tujuan-tujuan organisasi, yang pada waktu bersamaan juga mewujudkan tujuan-tujuan para pekerja secara perorangan".

Berbagai riset menunjukkan bahwa pelatihan yang efektif secara signifikan berpengaruh terhadap peningkatan proses kerja yang luar biasa pesatnya. Studi yang dilakukan Tall and Hall, misalnya, menghasilkan kesimpulan bahwa dengan mengombinasikan berbagai macam faktor seperti teknik pelatihan yang benar, persiapan perencanaan yang matang, serta komitmen terhadap esensi pelatihan, perusahaan dapat mencapai manfaat kompetisi yang sangat besar di dalam pasar yang sangat ketat (Sutrisno, 2011: 66).

Penyelenggaraan diklat yang dikelola oleh Balai Diklat Keagamaan Bandung merupakan serangkaian program dan kegiatan yang bertujuan untuk memfasilitasi peserta diklat dalam memperbaiki dan meningkatkan keterampilan serta kemampuan mereka untuk memperoleh efektivitas dalam pekerjaan mereka di masa sekarang dan yang akan datang melalui pengembangan kebiasaan pikiran dan tindakan, kecakapan, pengetahuan dan sikap, sehingga terwujudnya SDM profesional berdasarkan sistem diklat bersertifikat ISO.

Seperti telah dikatakan sebelumnya, bahwa keberhasilan penyelenggaraan suatu program pelatihan antaralain terletak pada kemampuan pengelolalatihan dalam mengelola setiap program kegiatan. Dengan kata lain penerapan aspekaspek manajemen dalam program ini mutlak diperlukan.

Menurut Malayu S.P. Hasibuan (2009: 2), "Manajemen adalah ilmu dan seni mengatur proses pemanfaatan sumber daya manusia dan sumber-sumber lainnya secara efektif dan efisien untuk mencapai suatu tujuan tertentu".

Menurut Al-Mu'ajm al-Wajiiz dalam Munir, et.al(2009: 9), "Istilah manajemen diartikan sebagai an-nizam atau at-tanzhim, yang merupakan suatu tempat untuk menyimpan segala sesuatu dan penempatan segala sesuatu pada tempatnya".

Adapun aktivitas manajerial (amaliah idariyyah) atau dikenal dengan sebutan fungsi-fungsi manajemen terdiri dari: perencanaan (takhtith), pengorganisasian (tanzhim), penggerakan (tawjib) dan pengendalian (riqabah) (Munir, et.al,2009: 9).

Perencanaan (takhtith) merupakan starting point dari aktivitas manajerial. Karena bagaimanapun sempurnanya suatu aktivitas manajemen tetap membutuhkan sebuah perencanaan. Karena perencanaan merupakan langkah 
awal bagi sebuah kegiatan dalam bentuk memikirkan hal-hal yang terkait agar memperoleh hasil yang optimal. Alasannya, bahwa tanpa adanya rencana, maka tidak ada dasar untuk melaksanakan kegiatan-kegiatan tertentu dalam rangka mencapai tujuan. Jadi, perencanaan memiliki peran yang signifikan, karena ia merupakan dasar dan titik tolak dari kegiatan pelaksanaan selanjutnya (Munir, et.al, 2009: 94-95).

Untuk mencapai tujuan yang hendak dicapai, maka pada dasarnya planner harus berani menjawab unsur-unsur perencanaan yaitu berupa pertanyaan apa, mengapa, dimana, kapan, siapa yang melakukan, dan bagaimana cara melakukan pekerjaan itu. Selain itu ada yang berpendapat bahwa perencanaan harus mengandung unsur-unsur tujuan perusahaan, politik perusahaan, prosedur perencanaan, budget dan program (Ya'qub: 1984: 64).

Adapun perumusan perencanaan yang dilakukan dalam program diklat meliputi studi penjajakan kebutuhan pelatihan, identifikasi kebutuhan pelatihan, merumuskan tujuan dan sasaran pelatihan, menentukan materi pelatihan, menyusun kurikulum dan silabus, memilih pelatih, menyeleksi peserta, menentukan waktu, tempat, dan sarana prasarana, menentukan metode, media dan biaya pelatihan (Kusnawan, et.al, 2009). Dengan mengoptimalkan perencanaan pada unsur-unsur pelatihan tersebut maka program pendidikan dan pelatihan akan berjalan secara efektif dan efisien.

Pengertian optimalisasi dalam Kamus Besar Bahasa Indonesia (Depdikbud, 1995: 628) berasal dari kata optimal yang berarti terbaik, tertinggi, sedangkan optimalisasi berarti suatu proses meninggikan atau meningkatkan. Sedangkan menurut W.J.S. Poerwadarminta (1997: 753), "Optimalisasi adalah hasil yang dicapai sesuai dengan keinginan, jadi optimalisasi merupakan pencapaian hasil sesuai harapan secara efektif dan efisien".

Salah satu upaya yang dilakukan untuk mengoptimalkan suatu perencanaan adalah melalui kegiatan analisis SWOT. SWOT (Strength, Weakness, Opportunity, and Threats) adalah serangkaian analisa mengenai kekuatan, kelemahan, peluang, dan tantangan untuk mengetahui seberapa besar ruang kemungkinan atas suatu grand design pekerjaan atau aktivitas yang akan kita lakukan.

Selanjutnya teori mengenai Tenaga Teknis Keagamaan. Dalam Kamus Bahasa Indonesia, "Tenaga teknis berarti karyawan yang bertugas membantu pimpinan di bidang keteknisan". Dan pengertian keagamaan Menurut W.J.S. Poerwadarminta adalah "Sifat yang terdapat dalam agama atau segala sesuatu mengenai agama". Dengan demikian, penulis menyimpulkan bahwa tenaga teknis keagamaan berarti karyawan yang bertugas membantu pimpinan di bidang keteknisan dan berbagai jenis pekerjaan yang memiliki sangkut paut dengan masalah agama. Dan itu juga berarti bahwa tenaga teknis keagamaan sama dengan sumber daya manusia yang dapat membantu sebuah organisasi dalam mencapai 
tujuannya.

Sumber Daya Manusia adalah orang-orang yang merancang dan menghasilkan barang atau jasa, mengawasi mutu, memasarkan produk, mengalokasikan sumber daya finansial, serta merumuskan seluruh strategi dan tujuan organisasi (Samsudin, 2010: 21).

Dengan demikian, penulis menyimpulkan bahwa Tenaga Teknis Keagamaan/SDM adalah individu yang bekerja sebagai penggerak suatu lembaga atau organisasi, dan merupakan aset yang harus dilatih dan dikembangkan kemampuannya agar dapat memberikan kontribusi terhadap organisasi dalam mencapai tujuannya secara efektif dan efisien.

Dalam PMA Nomor 75 Tahun 2015 tentang Penyelenggaraan Diklat pada Kementerian Agama disebutkan bahwa:

Balai Pendidikan dan Pelatihan Keagamaan yang selanjutnya disebut Balai Diklat Keagamaan adalah Unit Pelaksana Teknis Diklat Kementerian Agama yang berkedudukan di daerah dan mempunyai tugas melaksanakan Diklat Administrasi, Diklat Teknis Pendidikan dan Diklat Teknis Keagamaan bagi pegawai di wilayah kerja masing-masing dengan berpedoman kepada kebijakan Kepala Badan Penelitian dan Pengembangan serta Pendidikan dan Pelatihan Kementerian Agama.

\section{HASIL DAN PEMBAHASAN}

\section{Proses Perencanaan Diklat Tenaga Teknis Keagamaan di Balai Diklat Keagamaan Bandung}

Berdasarkan hasil wawancara penulis dengan Kepala Seksi Diklat Teknis Keagamaan, Idham (12 Oktober 2016) diperoleh informasi bahwa rangkaian proses perencanaan yang dilakukan Balai Diklat Keagamaan Bandung pada program Diklat Tenaga Teknis Keagamaan adalah: Pertama, melakukan Analisis Kebutuhan Diklat (Training Need Analisys/TNA). Kepala Seksi Diklat Teknis Keagamaan menyatakan bahwa:

Diklat yang ideal adalah diklat yang sesuai dengan kebutuhan user. Karena itu, kegiatan Analisis Kebutuhan Diklat (AKD) merupakan hal yang sangat penting untuk dilakukan sebelum menyelenggarakan program diklat. Untuk program diklat tahun 2016 maka AKDnya dilakukan pada tahun 2015. Dalam melakukan kegiatan AKD ini, para pegawai Balai Diklat Keagamaan Bandung ditugaskan untuk mendatangi daerah-daerah di setiap kabupaten/kota atau organisasi yang berada di bawah naungan Kementerian Agama dengan maksud untuk mengumpulkan dan menganalisis gejala-gejala atau keterangan-keterangan yang dapat menunjukkan adanya kekurangan 
dalam hal keterampilan, pengetahuan, dan sikap dari para pegawai (calon peserta latihan) yang ada di dalam organisasi tersebut, sehingga diklat yang akan dilaksanakan diharapkan cocok dengan masalah yang dihadapi peserta latihan serta dapat memenuhi kebutuhannya.

Pendapat serupa dikemukakan pula oleh Firman Nugraha, salah seorang widyaiswara bidang keagamaan (28 Desember 2016) yang mengatakan bahwa:

Dalam kegiatan Analisis Kebutuhan Diklat, kantor Balai Diklat Keagamaan Bandung membuat beberapa tim yang meliputi tim pembuat/penyusun instrumen, tim yang bertugas menyebarkan instrumen, dan tim pengolah hasil AKD. Kemudian, tim-tim yang telah dibentuk tersebut disebar kurang lebih ke 26 kabupaten/kota dengan membawa instrumen yang telah disiapkan oleh tim khusus untuk selanjutnya diisi oleh para responden/pegawai di daerah tersebut. Dalam instrumen tersebut terdapat satu pertanyaan terbuka yang memungkinkan setiap responden untuk mengisi instrumen tersebut dengan leluasa.

Jadi, kegiatan AKD ini bertujuan untuk mengumpulkan informasi yang berkaitan dengan pengetahuan, keterampilan serta sikap yang diperlukan calon peserta latihan untuk melaksanakan berbagai tugas dan tanggungjawabnya dalam suatu organisasi atau perusahaan. Intinya, "tujuan dari AKD ini adalah untuk memperoleh rekomendasi mengenai diklat apa yang akan dilakukan dalam satu tahun ke depan" (wawancara dengan Firman Nugraha, 28 Desember 2016).

Selain itu, kegiatan AKD sendiri dilakukan dengan sasaran untuk memperoleh beberapa hal, yaitu: Pertama, memperoleh peserta yang tepat (berkualitas). Kedua, memperoleh rumusan hasil yang akan dicapai. Ketiga, memperoleh gambaran tentang masalah dan hambatan yang bisa diatasi melalui pelatihan. Keempat, memperoleh gambaran tentang potensi dan sumber daya yang bisa ditingkatkan dalam pelatihan. Kelima, memperoleh gambaran materi, metode serta media yang sesuai dengan peserta latihan (wawancara dengan Kasi Diklat Teknis Keagamaan, 12 Oktober 2016).

Menurut Ahmad Musodik, salah seorang widyaiswara bidang keagamaan (01 November 2016) menjelaskan bahwa :

Kegiatan AKD ini dapat dilakukan dengan beberapa metode, yaitu melalui kegiatan survei, questioner, serta melalui kegiatan wawancara. Untuk diklat teknis keagamaan sendiri, widyaiswara bidang keagamaan di Balai Diklat Keagamaan Bandung telah menyiapkan instrumen berupa serangkaian pertanyaan berkenaan dengan berbagai kompetensi yang dimiliki oleh para responden/calon peserta latihan. Misalnya kompetensi yang harus dimiliki 
oleh calon penyuluh agama meliputi: Karya Tulis Ilmiah (14 item pertanyaan); Retorika (32 item pertanyaan); Strategi Bimbingan Penyuluhan (7 item pertanyaan); Objek Bimbingan Penyuluhan Generasi Muda (2 item pertanyaan); Objek Bimbingan Penyuluhan Majelis Ta'lim (3 item pertanyaan); Objek Bimbingan Penyuluhan Lembaga Pemasyarakatan (5 item pertanyaan); Objek Bimbingan Penyuluhan Dinamika Sosial (5 item pertanyaan); Metodologi Bimbingan Penyuluhan (10 item pertanyaan); Media Bimbingan Penyuluhan (6 item pertanyaan), dll.Contoh lainnya misalnya kompetensi yang harus dimiliki oleh calon penghulu, terdiri dari 62 pertanyaan yang meliputi berbagai kompetensi yang berbeda.

Setelah hasil AKD diperoleh, selanjutnya pegawai Balai Diklat Keagamaan Bandung (tim pengolah) membuat urutan peringkat dari diklat yang diinginkan oleh para calon peserta diklat, biasanya Balai Diklat menggunakan strategi "Taylor Made", dalam arti diklat itu dilakukan sesuai dengan permintaan atau kebutuhan calon peserta latihan (wawancara dengan Ahmad Musoddik, 01 November 2016).

Kedua, melakukan rapat koordinasi dengan satuan organisasi di wilayah kerja Balai Diklat. Setelah AKD selesai dilakukan, Pusdiklat dan Balai Diklat Keagamaan Bandung melakukan rapat koordinasi dengan satuan organisasi di wilayah kerja Balai Diklat. Dalam kegiatan rakor tersebut disampaikanlah program diklat yang dibutuhkan sesuai dengan hasil AKD. Kemudian hasil dari AKD itu dibuatlah TOR untuk diusulkan ke perencana untuk kemudian diusulkan sebagai program diklat. Dan setelah diusulkan ke perencana, nanti akan turunlah keputusan mengenai diklat apa saja yang akan dilakukan beserta jumlah angkatannya. Misalnya untuk Diklat Teknis Keagamaan sekian angkatan dan untuk Diklat Administrasi sekian angkatan. Dan penentuan program diklat tersebut disesuaikan dengan prioritas serta anggaran yang ada. Karena walaupun kebutuhan diklat sangat banyak, tetap tidak bisa diselenggarakan jika anggarannya tidak ada, karena itu dipilihlah program diklat yang paling urgen (wawancara dengan Kasi Diklat Teknis Keagamaan, 12 Oktober 2016).

Penentuan mengenai program diklat apa saja yang akan dilakukan didasarkan pada dua hal, pertama, didasarkan pada hasil Analisis Kebutuhan Diklat (AKD) dan kedua, didasarkan pada Rencana Kerja Pemerintah (RKP). (wawancara dengan Firman Nugraha, 28 Desember 2016). Misalnya untuk tahun 2016 dalam RKP telah ditetapkan bahwa diklat fungsional calon penghulu terdiri dari 12 angkatan, namun ternyata anggarannya tidak ada, sehingga Balai Diklat melakukan assesment dan diturunkanlah menjadi 3 angkatan. Satu hal yang perlu ditegaskan bahwa program diklat yang ditetapkan dalam RKP sifatnya tidak bisa diganggu gugat dan mutlak harus dilakukan (wawancara dengan Kasi Diklat 
Teknis Keagamaan, 12 Oktober 2016).

Setelah penentuan diklat selesai dilakukan, selanjutnya Balai Diklat membuat rancangan program diklat berdasarkan hasil Analisis Kebutuhan Diklat yang sesuai dengan jenjang dan kewenangannya. Rancangan program diklat ini dapat diselenggarakan setelah mendapatkan persetujuan atau mendapat penugasan dari Kepala Badan (wawancara dengan Kasi Diklat Teknis Keagamaan, 12 Oktober 2016).

Ketiga, penentuan panitia penyelenggara diklat. Panitia diklat ini ditetapkan oleh Kepala Balai Diklat Keagamaan Bandung atas usul Kepala Seksi Diklat Teknis Keagamaan dan ditetapkan paling lambat tiga minggu sebelum pelaksanaan diklat dimulai. Mereka terdiri dari unsur staf/pejabat struktural maupun fungsional. Susunan panitia diklat terdiri dari ketua, sekretaris/bidang akademis, dan anggota/staf pelaksana. Ketua panitia diklat ini bertanggungjawab kepada Kepala Balai Diklat (SK Kepala Badan Litbang dan Diklat Kemenag No. BD/21/2013: 14-15).

Keempat, mengadakan rapat persiapan. Berdasarkan hasil studi dokumentasi penulis terhadap riwayat notulensi rapat persiapan Diklat Teknis Keagamaan yang dilaksanakan pada hari Kamis tanggal 12 Mei 2016 (pukul 16.00 s.d. 20.00 WIB) di Aula Balai Diklat Keagamaan Bandung, Gedung Djuhany Sumantadisastra diperoleh informasi bahwa pelaksanaan rapat persiapan diklat teknis berjalan dengan baik, dengan susunan acara sebagai berikut: 1) Pembukaan dan pengarahan Kepala Balai Diklat Keagamaan Bandung selaku pemimpin rapat (Aep Syaefudin Firdaus).Dalam kesempatan tersebut, Kepala Balai Diklat Keagamaan Bandung memberikan pengarahan bahwa, "Kegiatan Diklat Teknis Keagamaan, kurikulumnya bersumber dari Pusdiklat Tenaga Teknis Pendidikan dan Keagamaan Kementerian Agama RI". Kemudian beliau juga menyampaikan bahwa,"Setiap panitia diharapkan dapat memberikan pelayanan yang prima terhadap peserta sebagai upaya untuk meningkatkan mutu layanan dan alumni yang berkualitas. Oleh karena itu, segala persiapan yang berhubungan dengan pelaksanaan diklat harus dipersiapkan dengan matang". 2) Pengarahan dari Ketua Panitia. Ketua memberikan pengarahan terkait persiapan yang harus dilakukan, yang meliputi: penentuan tempat, penyiapan struktur kurikulum, cross check peserta, penetapan dan pemanggilan narasumber, moderator, penyusunan jadwal, penyusunan panduan dan persiapan sarana dan prasarana.

Ketua panitia juga menyampaikan bahwa: a) Agar kegiatan berjalan lancar panitia harus memahami tugasnya masing-masing. Oleh karena itu, pembagian tugas harus ditetapkan sesuai dengan tugas pokok masing-masing panitia; b) Untuk panitia pelaksana, harap segera berkoordinasi dengan bagian tata usaha untuk mempersiapkan gedung kelas yang akan dipakai, aula untuk pembukaan, perlengkapan, ATK, dan lain-lain. Selain itu, panitia pelaksana juga harus 
berkoordinasi dengan seksi untuk memperoleh struktur kurikulum, panduan dan jadwal; c) Selanjutnya koordinasi dengan Kanwil Kementerian Agama Prov. Jabar untuk memperoleh gambaran mengenai siapa yang akan hadir untuk dapat memberikan pengarahan pembukaan materi kebijakan diklat teknis keagamaan; d) Dan terakhir, koordinasi dengan widyaiswara dan seksi diklat tenaga teknis untuk memperoleh informasi mengenai siapa yang akan mengajar dan penjadwalan moderator sesuai dengan mata diklat yang ada. 3) Tanya Jawab. 4) Kesimpulan yang berisi, "Agar kegiatan diklat berjalan dengan lancar, maka semua hal harus dipersiapkan dengan matang melalui koordinasi yang baik dengan pihak-pihak yang terkait dan setiap panitia diharapkan memahami dan melaksanakan tugas dan fungsinya masing-masing". 5) Penutupan rapat pada pukul 20.00 WIB dengan ditutup do'a oleh pemimpin rapat.

Kelima, penentuan waktu dan tempat.Setelah sebelumnya mengadakan rapat persiapan diklat, maka kegiatan selanjutnya adalah menentukan waktu dan tempat. "Waktu dan tempat diklat ini ditentukan oleh tim matrik dengan berkonsultasi kepada Kepala Balai. Untuk tempat diklat sendiri terbagi dua, pertama, Diklat Reguler dan kedua, Diklat di Tempat Kerja" (wawancara dengan Firman Nugraha, 28 Desember 2016). Hal tersebut sesuai dengan Keputusan Kepala Badan Litbang serta Diklat Kementerian Agama Nomor BD/21/2013 tentang Pedoman Penyelenggaraan Diklat Teknis di Lingkungan Kementerian Agama yang menyatakan bahwa:

Waktu dan tempat pelaksanaan diklat ditetapkan oleh Kepala Balai Diklat atas usul Kepala Seksi Diklat Teknis dengan mengacu pada Standar Kediklatan Teknis dan Rencana Kegiatan beserta anggarannya. Penentuan waktu dan tempat ini dilakukan paling lambat tiga minggu sebelum pelaksanaan diklat. Adapun untuk penentuan tempat diklat tidak harus selalu dilakukan di Balai Diklat, melainkan boleh dilakukan diluar kampus (Diklat Jarak Jauh/Diklat di Tempat Kerja) dengan mempertimbangkan ketersediaan sarana prasarana diklat dan atau tenaga ahli.

Keenam, penetapan dan pemanggilan peserta. Seperti halnya dalam penentuan waktu, tempat dan panitia, penetapan peserta diklat teknis keagamaan pada Balai Diklat Keagamaan Bandung ditetapkan pula oleh Kepala Balai Diklat atas usul Kepala Seksi Diklat Teknis Keagamaan setelah sebelumnya diadakan rapat persiapan/sarasehan oleh panitia.

Pemanggilan calon peserta diklat dilakukan melalui Kantor Wilayah Kementerian Agama Provinsi/Kantor Kementerian Agama Kabupaten/Kota dengan mencantumkan daftar nama calon peserta diklat dan/atau kuotanya, atau dalam kondisi tertentu dapat disampaikan langsung kepada atasannya. Penetapan dan pemanggilan calon peserta diklat ini dilakukan paling lambat sepuluh hari kerja sebelum pelaksanaan diklat. Surat pemanggilan calon peserta dapat disampaikan secara langsung, melalui pos, faximile, email, atau pengumuman pada website. 
Adapun penentuan jumlah, asal, dan kriteria peserta diklat mengacu pada Standar Kediklatan Teknis dan Rencana Kerja dan Anggaran (SK Kepala Badan Litbang dan Diklat Kemenag No. BD/21/2013: 17-18).

Penentuan calon peserta diklat ini bersifat selektif dengan memperhatikan kebutuhan organisasi dan pengembangan karir pegawai pada jabatan struktural, jabatan fungsional maupun jabatan teknis tertentu. Calon peserta diklat diusulkan oleh pimpinan unit organisasi dengan memperhatikan surat edaran/permintaan Balai Diklat. Selain itu, Balai Diklat berwenang untuk menolak calon peserta Diklat yang diusulkan jika tidak sesuai dengan persyaratan (PMA RI No. 75 Tahun 2015: 17).

Menurut Firman Nugraha (28 Desember 2016), "Penentuan peserta diklat ini ada yang melalui seleksi dan ada pula yang mendapatkan surat tugas dari Kemenag kabupaten/kota. Dan untuk seleksinya sendiri dilakukan oleh tim khusus yang ada di Kanwil, sedangkan Balai Diklat hanya menerima orang".

Adapun persyaratan yang harus dipenuhi oleh peserta Diklat adalah: 1) Sehat jasmani dan rohani; dan 2) Mendapat rekomendasi dari atasan langsung (PMA RI No. 75 Tahun 2015: 17).

Ketujuh, penetapan dan undangan narasumber dan moderator. Penentuan narasumber diklat ditetapkan oleh Kepala Balai Diklat Keagamaan berdasarkan hasil rapat persiapan, sedangkan moderator ditetapkan oleh ketua panitia diklat berdasarkan hasil rapat persiapan pula. Surat permohonan sebagai narasumber dan moderator dikirim paling lambat tiga hari kerja sebelum pelaksanaan diklat dimulai. Surat permohonan ini dilengkapi dengan nama mata diklat dan indikator capaian kompetensi serta dilampiri jadwal kegiatan. Dan satu hal yang tidak boleh dilupakan adalah penentuan narasumber dan moderator harus mengacu pada alokasi dan kriteria sebagaimana yang telah diatur dalam Standar Kediklatan dan Rencana Kerja dan Anggaran (SK Kepala Badan Litbang dan Diklat Kemenag No. BD/21/2013: 18-19).

Kasi Diklat Teknis Keagamaan juga mengatakan, "Dalam standar diklat itu sudah diatur mulai dari standar sarana prasarana, widyaiswara dan yang lainnya. Misalnya, penentuan widyaiswara atau narasumber harus disesuaikan dengan keahliannya/spesialisasinya, jadi tidak bisa sembarangan, karena nanti ada tim akreditasi".

Kedelapan, penyusunan jadwal. Penyusunan jadwal ini dilakukan paling lambat tujuh hari kerja sebelum pelaksanaan diklat dimulai. Jadwal ini sekurangkurangnya meliputi nama kegiatan, hari dan tanggal, waktu, nama mata diklat, jumlah jam pelajaran, nama widyaiswara/narasumber, dan nama moderator. Penyusunan jadwal mengacu pada Kurikulum Diklat Teknis dan Rencana Kegiatan dan Anggaran (SK Kepala Badan Litbang dan Diklat Kemenag No. $\mathrm{BD} / 21 / 2013: 20)$. 
Kesembilan, penyusunan panduan. Panduan pelaksanaan diklat ini sekurangkurangnya meliputi lembar biodata peserta, kata pengantar ketua panitia, pendahuluan, struktur kurikulum, persyaratan dan alokasi peserta, widyaiswara/narasumber, susunan panitia penyelenggara dan uraian tugasnya, waktu dan tempat pelaksanaan kegiatan, pembiayaan, kelulusan dan surat keterangan kediklatan, tata tertib di dalam dan di luar kelas, hak dan kewajiban peserta, dan jadwal kegiatan. Panduan pelaksanaan diklat ini harus selesai disusun paling lambat tiga hari sebelum pelaksanaan, kemudian dibagikan kepada seluruh panitia, peserta, dan narasumber untuk dijadikan sebagai pedoman selama pelaksanaan diklat berlangsung (SK Kepala Badan Litbang dan Diklat Kemenag No. BD/21/2013: 20-21).

Kesepuluh, persiapan sarana prasarana. Dua hari sebelum pelaksanaan diklat dimulai, panitia harus memeriksa kesiapan dari sarana prasarana yang akan digunakan selama kegiatan diklat berlangsung. Apabila ditemukan sarana prasarana yang belum lengkap atau kurang, maka panitia berkoordinasi dengan pegawai yang menangani tugas pengadaan/pemeliharaan sarana dan prasarana. Penyiapan sarana dan prasarana ini mengacu pada Standar Kediklatan Teknis dan Rencana Kerja dan Anggaran (SK Kepala Badan Litbang dan Diklat Kemenag No. BD/21/2013: 21).

Kesebelas, membuat laporan persiapan. Setelah berbagai persiapan mulai dari AKD hingga persiapan sarana prasarana selesai dilaksanakan, langkah selanjutnya adalah membuat laporan persiapan. Laporan persiapan penyelenggaraan diklat ini disampaikan oleh Kepala Balai Diklat kepada Kepala Badan Litbang dan Diklat dengan tembusan kepada Kepala Pusdiklat Tenaga Teknis Pendidikan dan Keagamaan.

Laporan persiapan ini disampaikan paling lambat empat hari sebelum penyelenggaraan diklat dilaksanakan. Laporan persiapan penyelenggaraan diklat ini berbentuk surat yang menginformasikan tentang: nama jenis diklat, dasar hukum penyelenggaraan diklat, tujuan dan sasaran, panitia penyelenggara, waktu dan tempat penyelenggaraan, pelaksanaan pembukaan, peserta, narasumber, dan sumber pembiayaan (SK Kepala Badan Litbang dan Diklat Kemenag No. BD/21/2013: 28).

\section{Faktor Pendukung dan Penghambat Proses Perencanaan Diklat Tenaga Teknis Keagamaan di Balai Diklat Keagamaan Bandung}

Untuk memperoleh informasi mengenai faktor pendukung dan penghambat proses perencanaan Diklat Tenaga Teknis Keagamaan di Balai Diklat Keagamaan Bandung, penulis melakukan analisis SWOT (Strength, Weakness, Opportunity, and Threats), yaitu serangkaian analisa mengenai kekuatan, kelemahan, peluang, dan kendala yang dimaksudkan untuk mengetahui seberapa besar ruang kemungkinan 
atas suatu grand design pekerjaan atau aktivitas yang akan di lakukan.Adapun hasil dari analisis SWOT tersebut adalah sebagai berikut:Pertama, Strength (Kekuatan). Menurut Idham, Kasi Diklat Teknis Keagamaan (12 Oktober 2016) kekuatan yang ada di BDK Bandung meliputi: 1) SDM atau Tenaga kediklatan (pengelola, penyelenggara, widyaiswara, dan narasumber/tenaga ahli) sudah memenuhi standar kualifikasi dan standar kompetensi yang diperlukan; 2) Kurikulum yang disusun, telah sesuai dengan prinsip-prinsip rancang bangun program diklat, mengacu pada hasil AKD, mengacu pada kebijakan pemerintah dan sesuai dengan dinamika kehidupan masyarakat; 3) Program Diklat Teknis sudah sesuai dengan Renstra dan mengikuti standar kediklatan; 4) Sarana prasarana yang ada di Balai Diklat Keagamaan Bandung sudah lengkap dan sesuai dengan standar kediklatan; 5) Metode dan media yang digunakan sudah sesuai dengan standar kediklatan; 6) Materi/bahan ajar dipersiapkan sebaik mungkin dan mengikuti standar kediklatan.

Pendapat lain dikemukakan oleh Firman Nugraha (28 Desember 2016) bahwasannya kekuatan yang ada di BDK Bandung terdiri dari: 1) SDM; 2) Anggaran dari DIPA; 3) Kurikulum dan Silabus (Kursil); 4) Memiliki status hukum.

Kedua, Weakness (Kelemahan). Menurut Ahmad Musodik (01 November 2016) kelemahan yang ada pada proses perencanaan di BDK Bandung adalah "waktu para widyaiswara terbagi dua/tidak fokus pada pekerjaan yang ada di Balai Diklat Keagamaan Bandung saja. Hal tersebut karena mereka memiliki pekerjaan lain di luar". Sedangkan menurut Firman Nugraha (28 Desember 2016) kelemahannya adalah "belum tentu semua dari hasil AKD bisa diambil karena anggaran yang terbatas".

Ketiga, Opportunity (Peluang) yang ada di BDK Bandung meliputi: 1) Teknologi yang semakin canggih memudahkan Balai Diklat Keagamaan Bandung dalam membangun jaringan/kerjasama, serta mempermudah dalam menyebarluaskan informasi tentang berbagai hal yang berhubungan dengan BDK Bandung kepada masyarakat luas; 2) Para stakeholder bersinergi untuk melakukan pengembangan kualitas SDM/kompetensi aparatur; 3) Kerjasama yang baik antara BDK Bandung dengan instansi para peserta Diklat; 4) Koordinasi yang baik antara BDK Bandung dengan satuan organisasi di wilayah kerja Balai Diklat (wawancara dengan Kasi Diklat Teknis Keagamaan, 12 Oktober 2016).

Dan menurut Firman Nugraha, peluangnya adalah, "Kerjasama dengan instansi berbasis MOU dan adanya Simdiklat, meskipun belum dioptimalkan untuk proses AKD".

Keempat, Threat (Kendala) yang ada di BDK Bandung meliputi: 1) Tidak semua program diklat yang dibutuhkan dapat diselenggarakan. Hal tersebut dikarenakan terbatasnya anggaran dari pemerintah; 2) Peserta diklat kadangkadang tidak sesuai dengan anggaran yang ada, misalnya dalam anggaran terdiri 
dari 30 orang sedangkan yang hadir kurang dari itu (wawancara dengan Kasi Diklat Teknis Keagamaan, 12 Oktober 2016).

Berdasarkan hasil analisis SWOT tersebut, maka penulis dapat menentukan faktor pendukung dan penghambat pada proses perencanaan Diklat Tenaga Teknis Keagamaan di Balai Diklat Keagamaan Bandung. Dimana strength (kekuatan) dan opportunity (peluang) menjadi faktor pendukung, serta weakness (kelemahan) dan threat (kendala) menjadi faktor penghambat.

\section{Strategi Balai Diklat Keagamaan Bandung dalam Mengoptimalkan Fungsi Perencanaan pada Program Diklat Tenaga Teknis Keagamaan}

Terdapat beberapa strategi yang diterapkan Balai Diklat Keagamaan Bandung dalam upaya untuk mengoptimalkan fungsi perencanaan pada program Diklat Tenaga Teknis Keagamaan, strategi tersebut meliputi:Pertama, mengikuti standar kediklatan yang telah ditentukan oleh pusat. Kedua, mengadakan Sistem Penjaminan Mutu Diklat Teknis. Ketiga, seluruh kegiatan perencanaan diklat berlandaskan pada Pedoman Penyelenggaraan Diklat Teknis di Lingkungan Kementerian Agama. Keempat, merencanakan untuk menyelenggarakan Diklat kerjasama. Kelima, senantiasa berkoordinasi dengan setiap staf dan satuan organisasi di wilayah kerja Balai Diklat.

Setelah melakukan penelitian di Balai Diklat Keagamaan Bandung dengan melalui berbagai langkah penelitian, mulai dari observasi ke lapangan secara langsung, kemudian melakukan wawancara dengan Kasubag TU, Kepala Seksi Diklat Tenaga Teknis Keagamaan, dan juga beberapa widyaiswara bidang keagamaan, maka penulis dapat menyimpulkan bahwa proses perencanaan yang dilakukan di Balai Diklat Keagamaan Bandung pada program Diklat Teknis Keagamaan sejauh ini bisa dikatakan baik. Hal tersebut karena berbagai proses perencanaan yang dilakukan di Balai Diklat Keagamaan Bandung berlandaskan pada Pedoman Penyelenggaraan Diklat di Lingkungan Kementerian Agama, sehingga proses perencanaan mulai dari melakukan Analisis Kebutuhan Diklat hingga akhirnya membuat laporan persiapan semuanya sudah sesuai dengan standar kediklatan yang telah ditentukan oleh pusat.

Langkah awal dalam perencanaan Diklat adalah melakukan Analisis Kebutuhan Diklat. Dalam melakukan AKD ini, Balai Diklat Keagamaan Bandung membentuk beberapa tim untuk di kirim ke daerah dengan membawa instrumen yang telah disiapkan oleh tim khusus, yakni tim penyusun instrumen AKD. Hal tersebut dimaksudkan untuk mendapatkan informasi mengenai diklat apa yang saat ini dibutuhkan oleh para pegawai atau calon peserta diklat dengan menyelidiki kesenjangan antara apa yang seharusnya dilakukan dengan apa yang sebenarnya dilakukan. 
Hal tersebut sesuai dengan teori yang dikemukakan oleh Daryanto dan Bintoro (2014: 34), yaitu:

Pada prinsipnya, proses pengkajian kebutuhan pelatihan adalah melakukan pengkajian tentang ada tidaknya kesenjangan dalam penampilan kerja yaitu kesenjangan antara apa yang seharusnya dilakukan (merupakan ketentuan penampilan kerja/standar) dengan apa yang sebenarnya dilakukan (merupakan tingkat penampilan kerja yang dicapai atau yang dimiliki). Perbedaan inilah yang disebut dengan kesenjangan (gap).

Setelah kegiatan AKD selesai dilakukan, selanjutnya pegawai Balai Diklat mengolah hasil dari AKD tersebut dan menyusunnya berdasarkan prioritas. Jadi, dilihat diklat apa saja yang saat ini banyak dibutuhkan. Namun demikian, karena keterbatasan anggaran, maka tidak semua diklat yang dibutuhkan tersebut dapat diselenggarakan. Oleh karena itu, Balai Diklat hanya memilih program diklat yang sifatnya urgen (wawancara dengan Kasi Diklat Teknis Keagamaan, 12 Oktober 2016).

Terdapat tiga norma yang dipegang setiap Lembaga Diklat untuk menentukan prioritas tersebut, dan menurut penulis ketiga norma ini dipegang pula oleh Balai Diklat Keagamaan Bandung, yaitu: Pertama, dilihat dari segi kegawatannya, dalam artian seberapa besar akibat atau kerugian yang mungkin timbul jika masalah tersebut tidak segera ditangani melalui pelatihan. Kedua, dilihat dari segi mendesaknya, dalam artian kebutuhan akan pelatihan ini tidak bisa ditunda lagi. Ketiga, dilihat dari segi penyebarannya, artinya bagaimana tingkat penyebarannya jika masalah tersebut tidak langsung diatasi, atau suatu masalah yang jika tidak langsung diatasi dapat memicu atau menghadirkan masalah lainnya (Firdaus, et.al, 2009: 63-64).

Setelah penentuan prioritas tersebut selesai dilakukan, maka hasil AKD tersebut dibawa ke forum, yaitu rapat koordinasi dengan satuan organisasi di wilayah kerja Balai Diklat, dengan maksud untuk menyampaikan berbagai program diklat yang dibutuhkan. Kemudian, dibuatlah TOR untuk diusulkan ke perencana untuk selanjutnya ditetapkan sebagai program diklat. Selanjutnya Balai Diklat membuat rancangan program diklat, dan apabila telah mendapat persetujuan dari kepala badan maka rancangan program diklat tersebut dapat diselenggarakan (wawancara dengan Kasi Diklat Teknis Keagamaan, 12 Oktober 2016).

Langkah selanjutnya adalah penentuan panitia penyelenggara diklat yang terdiri dari unsur staf/pejabat struktural maupun fungsional. Susunan panitia diklat terdiri dari ketua, sekretaris/bidang akademis, dan anggota/staf pelaksana. Dimana ketua panitia diklat di sini bertanggungjawab kepada Kepala Balai Diklat. 
Kemudian melakukan rapat persiapan, menentukan waktu dan tempat, menetapkan dan memanggil peserta, menetapkan narasumber dan moderator, menyiapkan panduan, menyiapkan sarana prasarana dan terakhir membuat laporan persiapan. Dan semua kegiatan perencanaan tersebut mengikuti Pedoman Penyelenggaraan Diklat di Lingkungan Kementerian Agama serta disesuaikan dengan standar diklat teknis.

Menurut penulis, semua kegiatan perencanaan yang dilakukan di Balai Diklat Keagamaan Bandung sesuai dengan teori yang dikemukakan oleh Sondang P. Siagian yang mengatakan bahwa kegiatan perencanaan adalah mencari dan menemukan jawaban terhadap pertanyaan apa, siapa, mengapa, kapan (bilamana), dimana, dan bagaimana. Berbagai pertanyaan beserta jawaban dari kegiatan perencanaan tersebut adalah:Pertama, Apa: 1) Apa yang akan dikerjakan? program diklat. 2) Sumber dana apa yang dibutuhkan? anggaran, baik dari pemerintah maupun dari non pemerintah. 3) Sumber daya apa yang dibutuhkan? sumber daya manusia yang profesional (tenaga kediklatan, mulai dari pengelola, penyelenggara, widyaiswara, serta tenaga ahli). 4) Sarana prasarana apa yang diperlukan? kelas, aula, asrama, ATK, dll.Kedua, Siapa:Siapa yang akan melaksanakan kegiatan tersebut? pengelola, penyelenggara, widyaiswara dan peserta diklat.Ketiga,Mengapa: menanyakan pertanyaan "mengapa" berarti berusaha melihat secara sangat teliti apakah dalam rencana yang disusun terdapat kelemahan-kelemahan atau tidak.Keempat, Kapan:Kapan pelaksanaan diklat ini akan dilakukan? waktu diklat ditetapkan oleh Kepala Balai, dan dalam setiap program diklat memiliki jangka waktu yang berbeda. Ada yang 10 hari, 12 hari, 15 hari, dst. Kelima,Dimana:Dimana kegiatan diklat akan dilaksanakan? bisa di kampus Balai Diklat dan bisa juga di tempat kerja atau diklat jarak jauh. Keenam, Bagaimana:Bagaimana kegiatan diklat ini akan dilaksanakan? mengikuti standar kediklatan dan juga pedoman penyelenggaraan diklat. Dengan ditemukannya jawaban yang meyakinkan terhadap keenam pertanyaan tersebut akan berakibat pada tersusunnya suatu rencana yang baik (Siagian, 2004: 46).

Optimalnya kegiatan perencanaan yang ada di Balai Diklat Keagamaan Bandung tersebut didukung dengan adanya Sumber Daya Manusia atau tenaga kediklatan yang sesuai dengan spesialisasinya, adanya status hukum, dan juga kurikulum, materi, media, metode serta sarana prasarana yang sesuai dengan standar kediklatan (wawancara dengan Idham dan Firman Nugraha).

Namun demikian, dalam setiap proses manajemen tidak mungkin jika tidak menemukan hambatan-hambatan yang menjadi kendala atau penghambat jalannya proses manajemen tersebut. Begitu pula yang dialami oleh Balai Diklat Keagamaan Bandung dalam proses perencanaannya. Salah satu hal yang menjadi penghambat proses perencanaan tersebut adalah terbatasnya anggaran dari pemerintah (wawancara dengan Idham). Saat ini banyak sekali orang-orang yang 
membutuhkan akan pelatihan dengan berbagai macam jenis pelatihan yang berbeda, sedangkan anggaran yang disalurkan oleh pemerintah belum bisa mewujudkan hal tersebut. Dari sekian banyak jenis pelatihan hanya beberapa jenis pelatihan yang dapat diselenggarakan dalam setiap tahunnya.

Meski demikian, Balai Diklat Keagamaan Bandung memiliki strategi untuk meminimalisir anggaran tersebut, yaitu dengan mengadakan diklat kerjasama (wawancara dengan Idham). Diklat kerja sama ini dilakukan di tempat kerja para peserta diklat dengan anggaran diklat bukan dari pemerintah, dan Balai Diklat hanya sebagai penyelenggara saja.

Selain itu Balai Diklat Keagamaan Bandung juga menerapkan beberapa strategi agar kegiatan perencanaan diklat berjalan dengan optimal, strategi tersebut meliputi: senantiasa berupaya untuk memenuhi standar kediklatan, mengikuti penjaminan mutu yang dilakukan oleh pusat, senantiasa berpedoman pada pedoman penyelenggaraan diklat, dan juga senantiasa melakukan koordinasi dengan setiap pegawai Balai Diklat dan satuan organisasi di wilayah kerja Balai Diklat (wawancara dengan Kasi Diklat Teknis Keagamaan, 12 Oktober 2016).

Dan menurut penulis, semua strategi tersebut dapat membantu dalam mengoptimalkan kegiatan perencanaan yang berimplikasi pada pencapaian tujuan diklat sendiri, yaitu terwujudnya Sumber Daya Manusia Aparatur Kementerian Agama yang profesional.

Demikianlah gambaran hasil penelitian yang telah penulis lakukan. Menurut penulis, pemilihan metode deskriptif yang penulis gunakan dalam penelitian ini sangat cocok, karena pada akhirnya penulis dapat menggambarkan/melukiskan keadaan obyek penelitian pada saat sekarang secara luas dan mendalam juga didasarkan pada fakta-fakta yang tampak atau sebagaimana adanya.

\section{PENUTUP}

Berdasarkan hasil penelitian yang dilakukan di Balai Diklat Keagamaan Bandung, diperoleh kesimpulan sebagai berikut: 1) Proses perencanaan pada program Diklat Teknis Keagamaan di Balai Diklat Keagamaan Bandung meliputi: pelaksanaan kegiatan Analisis Kebutuhan Diklat (AKD) yang dimaksudkan untuk mengumpulkan dan menganalisis gejala-gejala atau keterangan-keterangan yang dapat menunjukkan adanya kekurangan dalam hal keterampilan, pengetahuan, dan sikap dari para pegawai (calon peserta latihan) yang ada di dalam suatu organisasi. Selanjutnya pelaksanaan rapat koordinasi dengan satuan organisasi di wilayah kerja Balai Diklat, penentuan panitia penyelenggara diklat, pelaksanaan rapat persiapan, penentuan waktu dan tempat, penetapan dan pemanggilan peserta, penetapan dan undangan narasumber dan moderator, penyusunan jadwal, penyusunan panduan, 
persiapan sarana prasarana, dan terakhir penyusunan laporan persiapan. 2) Faktor pendukung proses perencanaan diklat teknis keagamaan di Balai Diklat Keagamaan Bandung meliputi: a) Tenaga kediklatan (pengelola, penyelenggara, widyaiswara, dan narasumber/tenaga ahli) sudah memenuhi standar kualifikasi dan standar kompetensi yang diperlukan; b) Program Diklat Teknis yang ada sudah sesuai dengan Renstra dan mengikuti standar kediklatan; c) Kurikulum yang disusun, telah sesuai dengan prinsip-prinsip rancang bangun program diklat, mengacu pada hasil AKD, mengacu pada kebijakan pemerintah dan sesuai dengan dinamika kehidupan masyarakat; d) Memiliki status hukum; e) Sarana prasarana yang ada di Balai Diklat Keagamaan Bandung sudah lengkap dan sesuai dengan standar kediklatan; f) Metode dan media yang digunakan sudah sesuai dengan standar kediklatan; g) Materi/bahan ajar dipersiapkan sebaik mungkin dan mengikuti standar kediklatan; h) Teknologi yang semakin canggih memudahkan Balai Diklat Keagamaan Bandung dalam membangun jaringan/kerjasama, serta mempermudah dalam menyebarluaskan informasi tentang berbagai hal yang berhubungan dengan BDK Bandung kepada masyarakat luas; i) Para stakeholder bersinergi untuk melakukan pengembangan kualitas SDM/kompetensi aparatur; j) Koordinasi yang baik antara BDK Bandung dengan satuan organisasi di wilayah kerja Balai Diklat.Adapun yang menjadi faktor penghambatnya meliputi: a) Tidak semua program diklat yang dibutuhkan dapat diselenggarakan, hal tersebut dikarenakan terbatasnya anggaran yang disalurkan oleh pemerintah; b) Peserta diklat kadang-kadang tidak sesuai dengan anggaran yang ada. Misalnya dalam anggaran terdiri dari 30 orang, sedangkan pada saat pelaksanaan kurang dari itu; c) Waktu para widyaiswara terbagi dua/tidak fokus pada pekerjaan yang ada di Balai Diklat Keagamaan Bandung saja. Hal tersebut karena mereka memiliki pekerjaan lain di luar. 3) Strategi Balai Diklat Keagamaan Bandung dalam mengoptimalkan proses perencanaan pada program Diklat Teknis Keagamaan adalah sebagai berikut: a) Mengikuti Standar Kediklatan yang telah ditentukan oleh pusat; b) Mengadakan sistem penjaminan mutu diklat teknis; c) Seluruh kegiatan perencanaan berlandaskan pada Pedoman Penyelenggaraan Diklat Teknis di Lingkungan Kementerian Agama; d) Merencanakan untuk menyelenggarakan diklat kerja sama; e) Selalu berkoordinasi dengan setiap staf serta lembaga atau satuan organisasi di wilayah kerja Balai Diklat.

\section{DAFTAR PUSTAKA}

Achmadi I. (2012). Optimalisasi, diakses 26 Juli 2016, dari http:/ /indraachmadi.blogspot.co.id/2012/04/optimalisasi.html.

Alfarisi R. (2009). Hubungan Efektivitas Pelatihan Sistem Manajemen Berbasis Kompetensi dengan Kinerja Karyawan. Skripsi, Fakultas Ekonomi dan Manajemen Institut 
Optimalisasi Fungsi Perencanaan pada Program Pendidikan dan Pelatihan Tenaga Teknis Keagamaan di Balai Diklat Keagamaan Bandung

Pertanian Bogor.

Daryanto \& Bintoro. (2014). Manajemen Diklat. Gava Media; Yogyakarta

Firmansyah D. (2015). Laporan Realisasi Pendidikan dan Pelatihan di Balai Diklat Keagamaan Bandung Semester 1 Tahun 2015, diakses 25 Juli 2016, dari http:/ / balitbangdiklat.kemenag.go.id/download/read/979-laporansimdiklat-bdk-bandung-semester-1-tahun-2015.

Hasibuan, S.P., M.. (2006). Manajemen: Dasar, Pengertian dan Masalab. Jakarta: Bumi Aksara.

Kamus Bahasa Indonesia Online, Definisi Tenaga, diakses 03 Agustus 2016, dari http://kamusbahasaindonesia.org/tenaga/mirip.

Kusnawan A \& Aep F S. (2009). Manajemen Pelatihan Dakwah. Rineka Cipta; Jakarta Machasin. (2012). Keputusan Kepala Badan Penelitian dan Pengembangan serta Pendidikan dan Pelatihan Kementerian Agama Nomor BD/60/2012 tentang Standar Kediklatan Teknis Kementerian Agama. Jakarta.

Machasin. (2013). Keputusan Kepala Badan Penelitian dan Pengembangan serta Pendidikean dan Pelatihan Kementerian Agama Nomor BD/21/2013 tentang Pedoman Penyelenggaraan Diklat Teknis di Lingkungan Kementerian Agama. Jakarta.

Machasin. (2015). Keputusan Kepala Badan Penelitian dan Pengembangan serta Pendidikan dan Pelatihan Kementerian Agama RI Nomor 57 Tabun 2015 tentang Pedomana Penyelenggaraan Pendidikan dan Pelatihan Kerja Sama di Lingkungan Badan Penelitian dan Pengembangan serta Pendidikan dan Pelatiban Kementerian Agama. Jakarta.

Munir \& Wahyu I. (2009). Manajemen Dakwah. Kencana; Jakarta

Poerwadarminta, W.J.S. (1976). Kamus Umum Bahasa Indonesia. Balai Pustaka; Jakarta

Riadi M. (2015). Strength, Weakness, Opportunity, Threat (SWOT), diakses 06 Februari 2017, dari http://www.pengertianku.net/2015/03/pengertian-analisisswot-dan-manfaatnya.html.

Saifuddin H L. (2015). Keputusan Menteri Agama RI Nomor 75 Tahun 2015 tentang Penyelenggaraan Pendidikan dan Pelatihan Pegawai pada Kementerian Agama. Jakarta.

Samsudin S. (2010). Manajemen Sumber Daya Manusia. Pustaka Setia; Bandung

Siagian P S. (2012). Fungsi-fungsi Manajerial. Bumi Aksara; Jakarta

Sulastri L. (2010). Manajemen Sumber Daya Manusia Strategik. La Goods Publishing; Bandung

Sutrisno E. (2011). Manajemen Sumber Daya Manusia. Jakarta; Kencana.

Taufiq M. Quran in Word Ver 1.0.0. Taufiq Product.

Tulung, M J. (2014). "Evaluasi Program Pendidikan dan Pelatihan Kepemimpinan Tingkat IV di Balai Diklat Keagamaan Manado.” dalam Journal “Acta Diurna" Volume III. No. 3 Tahun 2014. 
Y, Adicahya.

Wajdi F. (2012). Definisi Agama dan Keagamaan. diakses 03 Agustus 2016, dari https://www.academia.edu/20127276/Defenisi_agama_dan_keagamaan. Ya'qub H. (1984). Manajemen Kepemimpinan: CV. Diponegoro; Bandung 